\title{
Petroleum Sector Reform And The Development Of The Public Health Sector Of The Nigerian Economy
}

\author{
Ndifreke S. Umo-Udo (Ph.D) \\ Department of Political Science and Public AdministrationUniversity of Uyo, Uyo, Akwa - Ibom State, Nigeria.
}

\begin{abstract}
This paper examined the effects of the deregulation of the petroleum sub-sector on the public health sector of the Nigerian economy during the Olusegun Obasanjo administration. The data used in the study was obtained through the observations on primary and secondary sources and analysed with tables, percentages and correlation analysis. The findings revealed that despite government intervention, there is still poor quality and unavailability of health care services provided in the public hospitals which has led many to seek for health care provided by the private sector. The high cost of health care in the private sector makes it an exclusive preserve of the rich while the poor resort to unqualified medical practitioners, patent medicine and the use of herbs. The paper recommends for increased funding, in the public health sector through provision of equipment, infrastructure and provision of subsidized health care for the poor.
\end{abstract}

Key Words: Deregulate healthcare, intervention, infrastructure, petroleum.

\section{INTRODUCTION}

The Nigerian state in a bid to reposition the petroleum sector of the economy has been carrying out some set of reforms in the sector. The reform which is as a result of the neo-liberal policies of the Bretton Woods Institutions is aimed at opening up the subsector for competition. Among the reforms is the attempt to deregulate and liberalise the downstream of the petroleum subsector. This is based on ensuring the free market enterprise whereby market forces will determine the prices and the wages. In Nigeria, the move is anchored on the provisions of the International Monetary Fund IMF and World Bank conditionalities on poor underdeveloped countries. The move began in 1986, with the adoption of the Structural Adjustment Programme, SAP, by the Ibrahim Babangida's administration. This led to the withdrawal of government in providing certain social services through its privatization and commercialization programmes and removal of subsidies on other goods and services provided to the people. The implication of this on the political economy of Nigeria is that it has brought a deeper entrenchment or domination of global imperialism. There has been the intensification of struggles over rents and more specifically the attempt to re-order the rules under which the organizers of big businesses and their allies would share the country's wealth. This has led to the marginalization of the workers, the peasants and powerless groups in Nigeria. There has been a near total displacement of industries and the crippling of local capacity and initiative. The deepening contradictions rooted in the neo-liberal economic programmes are deeply demonstrated in the growing collapse of social infrastructures, the rise in the frequency and intensification of social conflicts and insecurity, lack of basic services to the people and the widening gap between the rich and the poor (ASUU Communiqué, 2008:30-31). Nations are forced to give up the push for a more export oriented economy. National ownership and the control of the economy continue to give way to emphasis on incentives to foreign investment and privatization of state businesses and their sale to foreign interest. This coupled with the policy reforms of the Structural Adjustment Programmes (SAP) being foisted on the developing countries by the World Bank and the International Monetary Fund (IMF) to minimize the government interventionist role by reducing public ownership, subsidies and regulation. The consequence of this on development as noted by Offiong (2001) is that intentional or otherwise, social services have been very seriously and negatively affected.

\section{STATEMENT OF PROBLEM}

Countries all over the world react in various ways to cope with the intensification of globalization and the neo-liberal policies of the west. In Nigeria, public wealth is increasingly privatized, misappropriated and stolen to the detriment of a majority of Nigerians thus aggravating the situation and making the country more vulnerable to violence. There is less public funding for health, education and other critical sectors of the economy. The proportion of the annual federal budget for the health sector has been on the decline since independence in 1960. Other public infrastructures that are indispensable for the development of the productive forces of the country have been neglected. The situation has also led to the implementation of many anti people policies which are detrimental to development. The retrenchment of workers, non-payment, poor payment and 
late payment of workers, denial of workers benefits, removal of subsidy on petroleum products leading to the increase in the pump price of petroleum products, sale of the peoples' property to a few individuals especially to the rulers themselves and their agents under the guise of privatization programme, describes the prevailing situation in Nigeria (Ogban-lyam, 2005: 39). The Nigerian government under the Olusegun Obasanjo administration carried out certain reforms through the liberalization of the petroleum subsector. This was referred to as the process of deregulation which led to the removal of subsidies from domestic petroleum products and the attendant increase in the cost of the product. The argument of the administration was that government resources previously used for subsidizing petroleum products will be freed to undertake more developmental projects and programmes such as construction of good roads, clinics, hospitals, schools and provision of good drinking water, etc, for the benefit of the general public and especially the rural poor. (Gbadamosi, Kukpolukun and Oluleye, 2008). There is therefore, the need to evaluate the success of this policy vis a vis the public health sector in Nigeria.

Accordingly, this research shall be guided by the research question:

(1) Was there any significant positive relationship between the deregulation of the downstream of the petroleum sector and the development of the public health sector of the Nigerian economy?

\section{OBJECTIVES OF THE STUDY}

In carrying out this study, the broad objective of the study was to understand the effects of deregulation on the public health sector of the Nigerian Economy. Its specific objectives were to:

(i) Examine the effect of handing over the provision of critical public services to private enterprise;

(ii) Examine the impact of public health sector of the Nigerian economy within the period 2003-2007;

\section{Literature Review}

Owens (2004) reacting to the government and civil society battle over economic reforms, admits that the Nigerian economy is approaching paralysis. He observes that though the government is dead set on implementing IMF endorsed price reforms, which would raise fuel prices by eliminating subsidies. Yet the vast majority of Nigerians adamantly oppose the move, claiming it would impoverish them. Such price hikes has often frozen the entire sectors of the economy in the grip of a general strike opposing the government plan to raise fuel prices. The citizens view the reforms which are backed by the IMF as an attempt to increase the pains of hardship as this will lead to an escalation in the cost of social services such as health care and transportation. Commenting on the position of labour in the plans to deregulate the downstream sector of the Nigerian oil industry, Chigbo (2009) expressed the position of the former Nigeria Labour Congress President, Abdulwaheed Omar and the position of labour; that government has not put in place any serious measure to cushion the spiral effects the policy would have on the people. This is more so when there is abject neglect of infrastructure and social amenities in the country. The poor state of roads, health institutions, water, and electricity does not encourage the average Nigerian to support any move by government to remove subsidy which he believes is the only thing he is benefiting from government's inept management of the nation's affairs. In his work on "The Impact of Oil on a Developing Country" (Ikein, 1990) maintains that health facilities in Nigeria remain most spatially disproportionate, a situation that poses the utmost disadvantage to rural residents. The better funded and equipped health facilities are located in urban centres. He observes that there is a dual health care system in which western scientific medicine exists side by side with traditional health care systems, and is often in direct competition with each other. Moreover, there is unequal access to Western medicine as many people, particularly those in the rural areas and low income group, rely on traditional herbal medicines since it is easier to acquire, and herbalists are more accessible and affordable than doctors in the less populated areas. This dualism in health care facilities has a significant impact on the country's morbidity. Statistics show that the infant mortality rate is 193 per 1000 for rural areas and 94 per 1000 for urban areas. The average ratio of physicians per capita is one in 12,550 people while the average life expectancy was put at 48.6 years. However, this was based on a 1985 statistical survey which was conducted by the then Federal Office of Statistics (FOS) in Nigeria. Commenting on the "Crimes of globalization: Health care, HIV and the poverty of neoliberalism in sub-Saharan Africa" Ifeanyi Ezeonu is of the view that in rolling back state expenditure in such an important sector as the health care, the few health care options available to the poor have become even more limited. To him, the situation has been exacerbated by the requirements of the Uruguay Round Trade-Related Investment Measures (TRIMS) which even advances the neoliberal agenda further, and the Trade-Related Intellectual Property Rights (TRIPS) agreements which limit the access of many Africans to manage health crisis. (Ezeonu, 2008: 138). In the same vein, Ogunbekun, Ogunbekun and Orabaton (1999) attest to this claim that the persistently low quality and inadequacy of health services provided in public facilities has made the private sector an unavoidable choice for consumers of health care in Nigeria. Ineffective state regulation however has meant little control over the clinical activities of private sector providers while the cost of medical services has, 
in recent years been very expensive coupled with the rate of inflation. Baker (2008) in observance of the World Bank and International Monetary Fund Policy influence in Nigeria's energy sector states that the privatization process of the downstream of the oil and gas industry has seen strong opposition from labour groups over the absence of due diligence. The government is heavily criticized for its willingness to sell state assets without ensuring the development of national refining capacity, which would eventually remove the need to import much of the refined petroleum products that Nigeria consumes. According to her, although the federal government spent a total of $\$ 18.6$ billion from 2000 - 2006 to import refined petroleum products, the oil workers have said that the amount spent on the importation of refined products could build at least six new refineries across the country and also lead to employment generation. Employment leads to increase income, which in turn leads to increase aggregate demand, investment and savings which also leads to improvement in living conditions such as good health care, housing and transport. She further stated that the failure in developing the refining capacity favours the few elites who benefit from the monopoly that they hold in the importation of refined petroleum products.

\section{THEORETICAL FRAMEWORK}

The theoretical exposition for explaining this work was "Dialectical materialism" as espoused under Karl Marx's Social Production theory. Dialectical materialism is concerned with the analysis of the fundamental relations of matter in motion. It is the science of the conditions and forms under which the various human societies have produced and exchanged and on this basis has distributed their products. Mankind is considered to be the highest stage of material development. Just like nature itself, so is human development subjected to dialectical processes of development. Dialectical materialism is sometimes seen as the complement of historical materialism (the materialist conception of history) which is the name given to Marx's methodology in the study of society, economics and history. Dialectical materialism makes reference to the claim by Marx that the history of all hitherto existing societies since written history is that of class struggles. The motion of any given society is to be understood in terms of the character of the contradictions of its constituent social elements. At certain stages, and of necessity, quantitative changes occur in a given order which result in such heightened social contradictions that a new, qualitatively higher, stage of social development results. (Whitefield, 1996). The members of the society enter into social relationships with each other for the purpose of social production. These social relationships are to begin within productive powers of the society. But it is the very increased productive power of the society which brings it into conflict with the social relationships. The social relationships, instead of being a help to the productive powers of the society, become fetters upon them and have to be cast off for further progress. It is in this sense that Marx brings in the famous class conflict in terms of which the movement of social history is traced. Whenever a new mode of production comes into being, the society finds its productive powers enhanced at the same time, a new social relation brings benefit (compared with the earlier situation) to the hitherto oppressed classes (for example, slaves become serfs or serfs become wage labourers). But the new social relationships in due course, bring to the notice of the society the fact that some classes are getting exploited by others (Bhatia, 1981: 281). The implication for the health sector is that neoliberal policies such as structural adjustment programmes have altered the level and nature of state involvement in the health care system. Since the policies generally entail a reduction in government involvement especially in spending, and a reduced role for the state in the provision of many goods and services. There is lower health expenditures with deleterious effects on the health status of the population, particularly the poor. This has led to low quality and inadequacy of health care services provided in public hospitals which in turn has made the private sector an unavoidable choice for those seeking for health care in Nigeria. The fees charged in private hospitals are expensive and affordable to the rich, with some of them traveling abroad for medical care while the poor are forced to patronize patent medicines stores, unqualified doctors and sometimes resort to the use of herbs whose quality is yet to be ascertained for health care.

\section{BUDGETARY PROVISIONS FOR HEALTH CARE DELIVERY IN NIGERIA}

Since the provision of access and improvement of facilities has long been a cornerstone of modern health care systems globally, public finance statistics and expenditure on the sector has increased due to the federal governments' decision to pay greater attention on the sector which was neglected thereby leading to deterioration in the state of facilities and services being offered in the nations' public health sector. A functional classification of Federal Government total capital expenditure during the period of this study shows that there was an increase in capital budgetary allocation of $\$ 6.4 \mathrm{~b}$ in $2003, \$ 18.2 \mathrm{~b}$ in $2004, \$ 21.8$ in 2005, $\$ 32.2$ billion in 2006 and $\$ 41.8 \mathrm{~b}$ in 2007 (see CBN Annual Report and Statement of Account 2007:198). While the percentage distribution of federal government's total expenditure (recurrent and capital) over the period reveals that $3.24 \%$ was expended on the health sector in 2003, 3.58\% in 2004, 4.21\% in 2005, 4.86\% in 2006 and $5.59 \%$ in 2007 (The NBS, Statistical Fact Sheet, 2007:45). 


\subsection{Hypothesis}

1) There exist a significant positive relationship between the deregulation of the downstream of the petroleum sector and the development of the public health sector of the Nigerian economy.

\section{Presentation of Data}

Table 1: Percentage increase/decrease in PMS Price Adjustment, 2003 - 2007

\begin{tabular}{|l|l|l|}
\hline Date/Year & Price (N/Litre) & $\begin{array}{l}\text { Percentage Increase/ } \\
\text { Decrease }\end{array}$ \\
\hline June 20, 2003 & From 26 to 40 & 53.7 \\
\hline July 9, 2003 & From 40 to 34 & 17.5 \\
\hline October 1, 2003 & From 34 to 42 & 17.5 \\
\hline May 29, 2004 & From 42 to 49.9 & 19 \\
\hline January, 2005 & From 49.9 to 50.5 & 1 \\
\hline August 26, 2005 & From 50.5 to 65 & 22.8 \\
\hline May 24, 2007 & From 65 to 75 & 15.4 \\
\hline June 23, 2007 & From 75 to 70 & 7.1 \\
\hline
\end{tabular}

\section{Source: PPMC}

Table 1 shows the percentage increase/decrease in PMS Price Adjustment in the study period 2003 2007. It shows that fuel price was increase and adjusted for a record of eight times.

Table 2: Percentage distribution of GDP of the public health sub-sector, 2003 - 2007

\begin{tabular}{|l|l|}
\hline Year & Percentage distribution \\
\hline 2003 & 0.4 \\
\hline 2004 & 0.4 \\
\hline 2005 & 0.4 \\
\hline 2006 & 0.4 \\
\hline 2007 & 0.4 \\
\hline
\end{tabular}

Source: NBS (Nigerian Statistical Fact Sheet, 2007:8)

Table 2 shows the analysis of the percentage distribution of the Gross Domestic Product at constant basic prices in the health sector indicates a dismal performance with a stagnant growth rate of $0.04 \%$ in 2003 , $0.04 \%$ in $2004,0.04 \%$ in $2005,0.04 \%$ in $2006,0.04 \%$ in 2007.

\section{Data Analysis}

Table 3: Correlation Analysis of Percentage Increase/Decrease in Fuel Pump Price and GDP of the Health Sector

\begin{tabular}{|c|c|c|c|c|c|}
\hline Year & $\begin{array}{c}\text { \% increase/ decrease } \\
\text { in fuel pump price } \\
\mathbf{X}\end{array}$ & $\begin{array}{c}\text { GDP of } \\
\text { Health } \\
\mathbf{Y}\end{array}$ & $\mathbf{X Y}$ & $\mathbf{X}^{\mathbf{2}}$ & $\mathbf{Y}^{\mathbf{2}}$ \\
\hline 2003 & 29.57 & 0.04 & 1.18 & 874.38 & 0.0016 \\
\hline 2004 & 19.00 & 0.04 & 0.76 & 361.00 & 0.0016 \\
\hline 2005 & 11.90 & 0.04 & 0.48 & 141.61 & 0.0016 \\
\hline 2006 & 0.00 & 0.04 & 0.00 & 0.00 & 0.0016 \\
\hline 2007 & 11.25 & 0.04 & 0.45 & 126.56 & 0.0016 \\
\hline & $\mathbf{7 1 . 7 2}$ & $\mathbf{0 . 2 0}$ & $\mathbf{2 . 8 7}$ & $\mathbf{1 5 0 3 . 5 5}$ & $\mathbf{0 . 0 1}$ \\
\hline
\end{tabular}

$\mathbf{H}_{\mathbf{0}}$ : There exist no significant positive relationship in the deregulation of the downstream of the petroleum sector and the development of the public health sector of the Nigerian economy.

$\mathbf{H}_{1}$ : $\quad$ There exist a significant positive relationship in the deregulation of the downstream of the petroleum sector and the development of the public health sector of the Nigerian economy.

Level of significance $=0.05$ 


$$
\begin{aligned}
& \text { Test Statistics } \quad \mathrm{t}=\frac{\mathrm{r}}{\sqrt{\frac{1-\mathrm{r}^{2}}{\mathrm{n}-2}}} \\
& \text { Where } \mathrm{r}=\frac{\mathrm{n} \sum \mathrm{xy}-\left(\sum x\right)\left(\sum y\right)}{\sqrt{\left[\mathrm{n} \sum \mathrm{x}^{2}-\left(\sum \mathrm{x}\right)^{2}\left[\mathrm{n} \sum \mathrm{y}^{2}-\left(\sum y\right)^{2}\right.\right.}}
\end{aligned}
$$

$\mathrm{n}=$ the number of paired observations $=5$

number of degrees of freedom $=n-2=5-2=3$

$$
\begin{aligned}
& \mathrm{t}-\text { table }=\mathrm{t}_{0.05}^{(\mathrm{n}-2)}=\mathrm{t}_{0.05}^{(3)}=2.35 \\
& \mathrm{r}=\frac{5(2.87)-(71.72)(0.20)}{\sqrt{\left.\left[5(1503.55)-(71.71)^{2}\right] 5(0.01)-(0.20)^{2}\right]}} \\
& =0.002 \\
& \mathrm{t}=\frac{0.002}{\sqrt{\frac{1-(0.002)^{2}}{3}}}=\frac{0.002}{\sqrt{\frac{1-000004}{3}}}=0.003
\end{aligned}
$$

Decision Rule: $\mathrm{H}_{0}$ is rejected if the calculated value of $\mathrm{t}$ is greater than its table value, and accepted otherwise.

Conclusion: Since the calculated value of $t=0.003$ is less than the table value of $t=2.35 . \mathrm{H}_{0}$ is accepted, hence there is no significant positive relationship in the deregulation of downstream of the petroleum sector and the development of the public health sector of the Nigerian economy.

\section{DISCUSSION}

Before the period of the study, the health sector was in a very bad shape, with the other sectors of the economy. It was one of the critical sectors that the government was making the argument for deregulation of the petroleum sector in order to intervene. Despite the increase in budgetary allocations and most components of health care spending, the health status of the average Nigerian and the condition of health infrastructure has not improved appreciably. Also, the poor continue to have a significant worse health status than the non poor and they (the poor) should be more strongly affected by public spending on health care relative to the non-poor. This could help reduce the difference in impact of spending between the poor and the non poor to be less substantial. In Nigeria, the cost of medical treatment is expensive. The absence of basic drugs in government hospitals has turned patients to acquire such drugs and services from private operators and providers which further increase the cost. The federal government under the Olusegun Obasanjo administration had contracted a private company Vamed Engineering for the procurement and installation of equipments in the various teaching hospitals across the country. In relation with the Vamed project, the hospitals required various degrees of renovation and rehabilitation work preparatory to the installation of the Vamed equipment. In this connection, some money had been allocated to each of the hospitals. Ahmadu Bello University Teaching Hospital ABUTH, for example, was allocated the sum of N260 million for pre-installation activities, followed in 2004 by another N50 million. The presidential committee sent a team to Ahmadu Bello University Teaching Hospital, ABUTH, Jos University Teaching Hospital, JUTH and University College Hospital, UCH to assess work progress. As at the end of 2004, ABUTH and $\mathrm{UCH}$ had achieved $100 \%$ of pre-installation projects and $80 \%$ equipment installation. In the case of the Jos University Teaching Hospital, work on the structure had not been completed to meet the requirements for Vamed equipment installation. A sum of N200 million was allocated to it in 2004 for the Vamed project, but the amount was only accessed in March 2005 to get the project underway after the due Process conditions were met. Some of the specific projects under the Vamed scheme include the completion of X-ray, Radiology with a theatre annex, completion of ward blocks, completion of external works for outpatient department and emergency buildings. (See Report on the implementation of the 2004 Budget, 2005) In 2005, N1.25 billion 
was released to the eight teaching hospitals to carry out the pre-installation and general maintenance works, while each Teaching Hospital was allocated Euros 7.9 for Vamed equipment. The Presidential Implementation Committee in collaboration with the Federal Ministry of Health which monitored these projects ascertained that the projects reached various stages of implementation. Out of the eight teaching hospitals, the renovations at UCH and ABUTH were completed and commissioned by President Olusegun Obasanjo. Out of the 20 projects which were to be executed by the Lagos University Teaching Hospital, LUTH as a pre-condition for the installation of Vamed equipment, 15 were completed as at the time of inspection while the remaining 5 were ongoing. Among them are the supply and the installation of one chiller and one boiler with contract sum of $\mathrm{N} 33.15 \mathrm{~m}$ and $\mathrm{N} 36.95 \mathrm{~m}$ respectively. Both projects were funded from the 2005 budget. (See Report in Implementation of 2005 Budget, 2006) At the University of Port Harcourt Teaching Hospital, UPTH which has now relocated to the permanent site, the sum of N156m which was allocated for its rehabilitation works in 2005 were fully released accessed and utilized for completion of work at Block A. The works completed include furnishing of administrative office, painting the interior and exterior of the building. The University of Port Harcourt Teaching Hospital, UPTH and University of Maiduguri Teaching Hospital, UMTH were to be commissioned before the end of 2006. Vamed had supplied the required equipment to almost all the teaching hospitals and were to be commissioned after installation. According to the study conducted by an interministerial committee led by the Federal Ministry of Finance on the implementation of the 2005 budget concludes that the impact of the Vamed project was being noticed and felt. With state of the art medical equipments now installed and used in some of the hospitals, improved medical services was to some extent available in the country, partly reducing the need to travel abroad for specialist services. In addition, the improved working environment has also served to motivate local medical personnel and discourage the trend of brain drain. But it was also discovered that most of the new equipments cannot be operated by the personnel since they have not been well trained to handle them. (See Report in Implementation of 2005 Budget, 2006). The country's health system after more than 30 years of recurrent reforms has witnessed serial policy somersaults. The health sector is still plagued with inadequate diagnostic facilities, under funding and poor working conditions. Although Vamed Engineering was awarded contract to revamp teaching hospitals across the country, yet, one of the pressing reasons why strikes persist in the health sector is as a result of lack of basic diagnostic and other medical equipment. The skeletal health system has forced wealthy Nigerians including President Umaru Musa Yar'Adua, to seek medical treatment abroad. The Federal Ministry of Health says Nigerians spend N32 billion yearly for medical treatment abroad.

\section{CONCLUSION}

In spite of the intervention, the health status of the average Nigerian and the condition of the health infrastructure has not improved considerably. The situation becomes worse in the case of the poor who cannot afford the cost of treatment sometimes offered in the private health facilities. The available infrastructure are inadequate and are ill equipped with inadequate diagnostic facilities. Another major problem has been that of funding as the workers are always threatening to go on strike as a result of the poor working conditions. Generally there is the absence or lack of basic drugs in these government owned hospitals which compounds the situation the more. The provision of equipment through the Vamed Intervention has been very selective in just about eight teaching hospitals across the country. This intervention should be in a large scale across various hospitals in the country. While the poor remuneration of health personnel has not only led to strike in the sector but loss of these personnel who travel abroad in search of greener pastures. This has also made them to go into private practice side by side with their work in the government hospitals. Needless to say that this of course is at the detriment of the public hospitals as much attention and focus is given to their private practice than that of the government. The spread of diseases such as HIV AID is on the increase, infant mortality rate and the maternal mortality ratio in Nigeria rank among the highest in the world, while the life expectancy ratio has also been on the decline. Government ought to conduct a more serious intervention in order to save the lives of Nigerians who cannot afford the high fees charged in private hospitals or travel abroad for medicare.

\section{RECOMMENDATIONS}

Government should increase funding of the health sector by improving equipments as well as the infrastructure and also subsidize health care delivery in order to ensure that poor people and majority of Nigerians can have access to it. Government should also ensure that drugs are provided in hospitals at reduced cost in order to ensure affordability. The Vamed intervention project in the eight tertiary institutions should be extended to other teaching hospitals, medical institutions and hospitals around the country so as to ensure even and more spread. Also the Vamed equipments installed at the teaching hospitals must be monitored, supervised and upgraded periodically to ensure that they do not malfunction or become obsolete. Medical personnels should be sent for training to enable them to manage and operate the newly installed Vamed equipments effectively. While improved working conditions and environment must be guaranteed to medical personnel to 
discourage the tide of brain drain and also stem the incessant and rampant cases of strikes in the nation's medical institutions which has often lead to casualties and loss of live.

\section{REFERENCES}

[1] Annual Report and Statement of Account (2007). Abuja: Central Bank of Nigeria.

[2] Baker, L. (2008). Facilitating whose power? WB and IMF policy influence in Nigeria's Energy Sector. http://www.brettonwoodsproject.org/art-561198. accessed on 15/04/2009.

[3] Bhatia, H.L. (1981). History of Economic Thought Third Rev. Ed. Delhi: Vikas Publishing House PVT Ltd.

[4] Chigbo, M. (2009). "The Ticking Deregulation Time Bomb" Newswatch, November 16.

[5] Comminique of the Meeting of the National Executive Council (NEC) of the Academic Staff Union of Universities (ASUU) held at the Imo State University (IMSU), Owerri, November 1-2, 2008". The Nation, Thursday, November 27, 2008.

[6] Ezeonu, Ifeanyi (2008). "Crimes of Globalization: Health Care, HIV and the Poverty of Neoliberalism in sub-Saharan Africa” International Journal of Social Inquiry Vol. 1 No. 2.

[7] Gbadamosi, R. Kukpolokun, F. and Oluleye, O. (2008). A Story of the Deregulation of the Nigerian Downstream Oil Sector. Abuja: Petroleum Products Pricing Regulatory Agency.

[8] Ikein, A.A. (1990). The Impact of Oil on a Developing Country: The Case of Nigeria. Ibadan: Evans Brothers (Nigeria Publishers) Limited.

[9] Offiong, D.A. (2001). Globalization: Post Neodependency and Poverty in Africa. Enugu: Fourth Dimension Publishers.

[10] Ogban-Iyam, O. (2005). "Societal Conflicts and the challenge of democracy in Nigeria". University of Nigeria Journal of Political Economy. Vol. No. 1.

[11] Ogunbekun, I., Ogunbekun, A. and Orabaton N. (1999). "Private Health Care in Nigeria: Walking the Tightrope". Oxford Journals, Health Policy and Planning. Vol. 14 No. 2 Oxford University Press.

[12] Owen, O. (2004). "Fueling a Crisis in Nigeria" Yale-Global Online, accessed on 04/04/2009.

[13] Report of the Inter-ministerial Committee on the Implementation of the 2004 Budget (2005). Abuja: Federal Ministry of Finance.

[14] Report of the Inter-ministerial Committee on the Implementation of the 2005 Budget. (2006) Abuja: Federal Ministry of Finance.

[15] Statistical Fact Sheet on Social and Economic Development (2007). Abuja: National Bureau of Statistics.

[16] Whitefield, S. (1996). "Dialectical Materialism" in lain Mclean (ed). Oxford Concise Dictionary of Politics Oxford: Oxford University Press. 